\title{
Origin and implications of low $V$ in eclogitic inclusions in diamond
}

\author{
SONJA AULBACH ${ }^{1}$ AND THOMAS STACHEL ${ }^{2}$
}

${ }^{1}$ Goethe University Frankfurt

${ }^{2}$ University of Alberta

Presenting Author: s.aulbach@em.uni-frankfurt.de

Cratonic eclogite is the product of Archaean and Palaeoproterozoic oceanic crust subduction into the subcontinental lithospheric mantle, and a fertile diamond source rock. In contrast to matrix minerals, inclusions in diamond (DI) are shielded from subsequent changes by their chemically inert host, and may thus contain more pristine information on the early state of the mantle. A detailed comparison of an extensive geochemical database of diamondiferous and barren eclogite xenoliths shows that some $50 \%$ of the latter could derive from a diamond-bearing source. The remainder is derived from sources that are too shallow or too heavily metasomatised for diamond stability and preservation.

As a multi-valent element that becomes less compatible in common mantle minerals with increasing oxidation state as a function of $f \mathrm{O}_{2}, \mathrm{~V}$ is a widely used elemental redox proxy. Some eclogites with $\mathrm{Eu} / \mathrm{Eu}^{*}>1$ have low $\mathrm{V}$ contents consistent with exclusion during low-pressure accumulation of olivine and plagiolase. For non-cumulate samples, V concentrations are similar for DI to corresponding minerals in xenoliths at a similar $\mathrm{MgO}$ content (as a proxy for the degree of differentiation in the oceanic crustal protolith). As inclusions equilibrated at higher average temperature, and rutile solubility in eclogitic garnet and clinopyroxene increases with temperature, similar V suggests a small effect of free rutile in the bulk rock. Since diamond formation is a metasomatic process, these observations could imply that (1) diamond formation did not entail significant redox changes, and (2) the cratonic eclogite reservoir did not significantly evolve with respect to $f \mathrm{O}_{2}$ conditions subsequent to diamond formation, e.g. via oxidative mantle metasomatism, whereby a higher average $\mathrm{V}$ oxidation state would cause diminished partitioning into garnet and clinopyroxene. This could explain why $\mathrm{V}$ is not clearly associated with mantle metasomatic indicators. Nevertheless, if V-poor DI do reflect a more pristine sample, the ambient convecting mantle, from which the oceanic crustal progenitors to the eclogites formed, was more reduced than its modern equivalent, as implied by eclogite xenoliths. 